\title{
Complement mediated cell death is associated with DNA fragmentation
}

\author{
MS Cragg ${ }^{\star, 1}$, WJ Howatt ${ }^{2}$, L Bloodworth ${ }^{1}$, \\ VA Anderson ${ }^{1}$, BP Morgan ${ }^{3}$ and MJ Glennie ${ }^{1}$ \\ ${ }^{1}$ Cancer Sciences Division, Tenovus Laboratory, Southampton University \\ Hospital, Southampton S016 6YD \\ 2 University Medicine, Southampton University Hospital, Southampton S016 \\ 6YD \\ ${ }^{3}$ Department of Medical Biochemistry, University of Wales College of Medicine, \\ Cardiff, CF4 4XN \\ * Corresponding author: MS Cragg, Cancer Sciences Division, Tenovus \\ Laboratory, Southampton University Hospital, Southampton S016 6YD, \\ Tel: 01703 798566; Fax: 01703 704061; E-mail: msc@soton.ac.uk
}

Received 8.7.99; revised 27.9.99; accepted 25.10.99

Edited by D Green

\begin{abstract}
In this study, we demonstrate for the first time that complement attack of target cells, in the presence of suitably high levels of serum, can induce the oligonucleosomal DNA fragmentation characteristic of apoptosis. This phenomenon requires membrane permeabilisation induced by formation of the complete membrane attack complex and relies on physiologically relevant levels of serum. TUNEL analysis detected complement mediated DNA fragmentation as early as $\mathbf{3 0 ~ \mathrm { min }}$ after the addition of serum and electron microscopy confirmed that chromatin became condensed after complement attack. Various experiments implicate serum DNase I as the mediator of this DNA fragmentation. Intriguingly, membrane permeability induced by melittin gave rise to similar serum dependent DNA fragmentation. The implications of these results for the study of apoptosis in vitro and in vivo are discussed. Cell Death and Differentiation (2000) 7, 48-58.
\end{abstract}

Keywords: complement; apoptosis; DNases; DNA fragmentation; cell death

Abbreviations: Ab, antibody; ATA, aurintricarboxylic acid; BSA, Bovine Serum Albumin; C, complement; HSA, Human Serum Albumin; mAb, monoclonal antibody; MAC, membrane attack complex; PI, propidium iodide

\section{Introduction}

Since the publication of the seminal paper by Kerr et $a l,{ }^{1}$ cell death has rigidly been classified as either necrotic or apoptotic. Necrotic death results from severe cell damage and is typified by osmotic dysregulation, cell swelling and, ultimately, cell lysis. Almost invariably inflammation occurs in the surrounding tissue. ${ }^{1-3}$ In contrast, apoptosis is typified by a controlled series of morphological and biochemical events which act in concert to prevent inflammation. Inflammation is clearly not a desirable outcome within a tissue and so it is no surprise that apoptosis is the predominant mode of death seen under physiological conditions in multicellular organisms. ${ }^{3-6}$

The changes which occur in an apoptotic cell include cytoplasmic shrinkage, membrane blebbing and chromatin condensation. Another event commonly observed in apoptotic cells, and one of the most readily detectable, is oligonucleosomal fragmentation of the nuclear DNA. This process is performed by endonuclease enzymes that cleave the DNA at nucleosomal distances, creating a socalled 'DNA ladder' which can be detected by agarose gel electrophoresis. DNA may also become degraded at late stages of necrosis, but fragmentation in this instance is predominantly due to the action of hydrolytic enzymes and does not result in internucleosomal cutting or a defined ladder. ${ }^{1,2,7}$ For this reason, detection of a DNA ladder is one of the most definitive diagnostic characteristics of apoptotic death. $2,7,8$

Recently it has become evident that the rigid characterisation of cell death as apoptotic or necrotic is too simplistic and that a broader range of death mechanisms than those typified by classic necrosis or apoptosis may well exist. Several reports demonstrate death mechanisms which are neither fully necrotic nor apoptotic, but which are a mixture of both. ${ }^{9-11}$ For this reason, it is now believed that a wide range of cell death mechanisms exists and that necrosis and apoptosis merely reflect the two physiological extremes. This proposal has led to the re-examination of a number of different modes of cell death and has recently led to the suggestion that hypoxia, classically considered to induce necrotic death, may involve typical features of apoptosis such as activation of endonuclease activity and signalling pathways. ${ }^{12}$

Like hypoxia, complement (C) induced death, resulting from C5b-9 lesions in target cell plasma membranes, has traditionally been cited as an inducer of necrotic death. ${ }^{2,3}$ However, a number of lines of evidence led us to believe that $\mathrm{C}$ induced death might also display features of apoptosis. Firstly, recent work by Papadimitriou et al ${ }^{13}$ has shown that chromatin condensation, typical of apoptosis, is present early during C attack of Ehrlich cells. Secondly, several authors have reported that $C$ death, at least for nucleated cells, is not merely a function of osmotic swelling and lysis, ${ }^{14}$ implying a mechanism more complex than classical necrosis. Thirdly, under conditions where the culture media has a higher (more physiological) osmotic potential, C attacked target cells lose their intracellular contents less rapidly. ${ }^{15}$ Finally, and perhaps most intriguingly, in 1971 Shipley et al reported that C 
attack induced rapid fragmentation of target cell DNA. ${ }^{16}$ Unfortunately, the relevance of oligonucleosomal DNA fragmentation was not appreciated at this time and further observations were not reported. With these data in mind, we undertook an in vitro study utilising six different neoplastic B-cell lines, to assess the mechanism by which C attacked cells die.

\section{Results}

To determine whether DNA fragmentation, a typical feature of apoptosis, was occurring in target cells after $C$ attack, we used a flow cytometric method. ${ }^{17}$ Apoptotic cells are seen in the sub-G1 peak of the DNA histograms (gated regions; see Figure 1), which represents degraded DNA. Figure 1 (top panels) shows that $\mathrm{C}$ attack in $30 \%$ human serum resulted in extensive DNA fragmentation of both Raji and Daudi B cells. To observe whether DNA fragmentation was dependent upon $C$ activity, $F\left(a b^{\prime}\right)_{2}$ antibody $(A b)$ fragments were used instead of intact $\operatorname{lgG}$, or $\mathrm{C}$ was rendered inactive through heating at $56^{\circ} \mathrm{C}$ for $30 \mathrm{~min}$. Using either of these strategies, $\mathrm{C}$ damage was not induced (data not shown) and DNA fragmentation was not evident (Figure 1). Thus DNA fragmentation occurred only in the presence of intact $A b$ and $C$.

To determine whether this was a common phenomenon and not a peculiarity of the cell lines chosen, a further four cell lines were assessed. As shown in Figure 2, all lines tested exhibited abundant DNA fragmentation within $18 \mathrm{~h}$ of C attack. Three representative cell lines, Ramos-EHRB, Daudi and Raji, were selected for more detailed analysis. Similar results were obtained with serum from guinea pig,

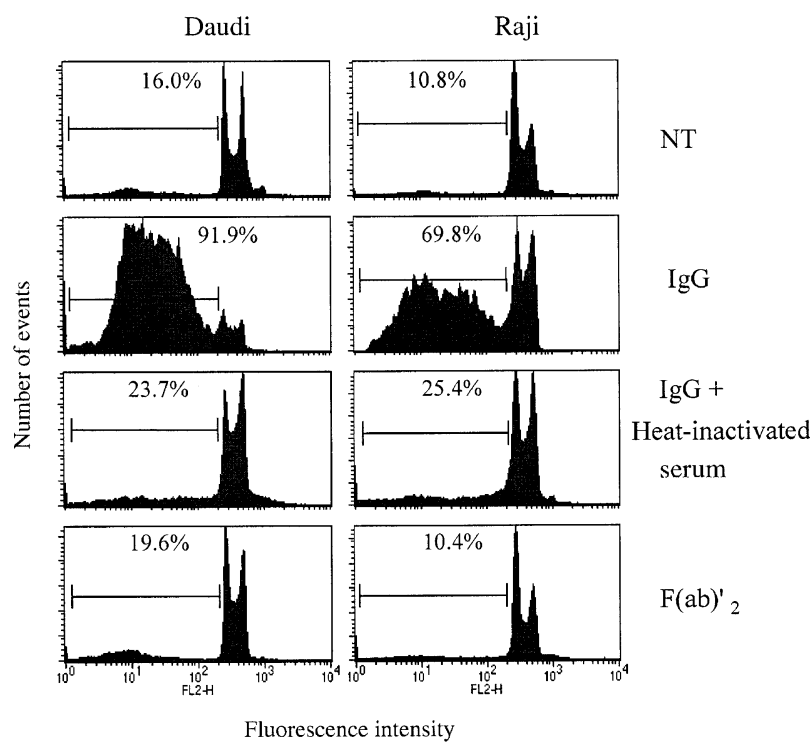

Figure 1 Requirement of $C$ activity for the induction of DNA fragmentation. Daudi or Raji cells $\left(5 \times 10^{5} \mathrm{ml}\right)$ were incubated with IgG or $\mathrm{F}\left(\mathrm{ab}^{\prime}\right)_{2}(7 \mu \mathrm{g} / \mathrm{ml}) \mathrm{Ab}$ fragments for $30 \mathrm{~min}$ at room temperature, prior to the addition of $30 \%$ normal or heat-inactivated serum. A cell sample was then taken $1 \mathrm{~h}$ after the addition of serum to assess the degree of membrane permeability using the PI assay (data not shown). The remainder of the cells were incubated at $37^{\circ} \mathrm{C}$ without washing for a further $18-24 \mathrm{~h}$. The extent of DNA fragmentation was then determined by the hypotonic PI assay. NT=no Ab added rat, sheep and rabbit, such that incubation with these sera generated DNA fragmentation in the target cells (data not shown).

We next investigated the requirement for Membrane Attack Complex (MAC) formation in the induction of DNA fragmentation. In C8-depleted serum MAC cannot form and so addition of $\mathrm{C} 8$ protein becomes the rate-limiting factor for MAC formation. Therefore, the level of MAC that can form increases proportionally with the amount of C8 protein that is added. As shown for EHRB and Raji cells (Figure $3 a, b)$ titration of $\mathrm{C} 8$ protein back into C8-depleted serum restored both membrane damaging (cell lysing) and DNA fragmentation activity to the serum in a dose-dependent fashion. In both cell lines, the amount of membrane permeability closely correlated with the extent of DNA fragmentation. These data demonstrate that C5b-9 MAC formation is both required for, and closely correlated with, the induction of DNA fragmentation.

Figure 4 shows results from a series of experiments in which we further explored the link between MAC dependent membrane damage and DNA fragmentation, by measuring propidium iodide $(\mathrm{PI})$ permeability and DNA fragmentation over a range of serum and $\mathrm{Ab}$ concentrations. Most informative were the experiments where the serum concentration was varied (Figure $4 \mathrm{a}$ ). These experiments revealed that the extent of DNA fragmentation induced was clearly dependent on the concentration of serum used. Only at the highest concentrations of serum did we observe significant DNA fragmentation. The concentrations of serum required to induce significant levels of membrane permeability were lower than those necessary for DNA fragmentation: for example, in EHRB cells maximum membrane permeability was obtained at $1 \%$ serum, whereas maximum DNA fragmentation required $30 \%$ serum. In contrast, when $\mathrm{Ab}$ concentration was varied with a constant concentration of serum (Figure $4 b$ ), DNA fragmentation was maximal only in samples that displayed maximal membrane permeability. These data indicate that membrane permeability induced by $\mathrm{C}$ is a pre-requisite for

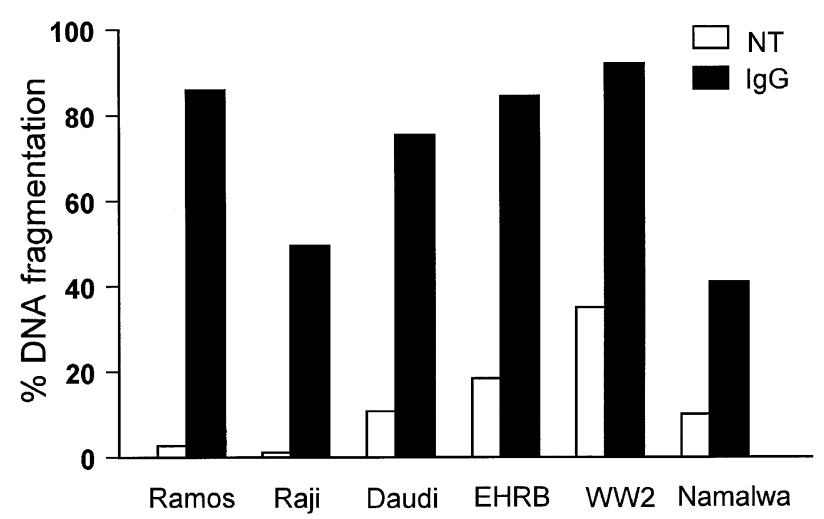

Figure 2 DNA fragmentation induced following $\mathrm{C}$ attack on different cell lines. Each cell line was incubated with $\mathrm{lgG}(7 \mu \mathrm{g} / \mathrm{ml})$ for $30 \mathrm{~min}$ at room temperature, prior to the addition of $30 \%$ human serum. Cells were then incubated and assessed as shown in Figure 1. NT=no Ab added 


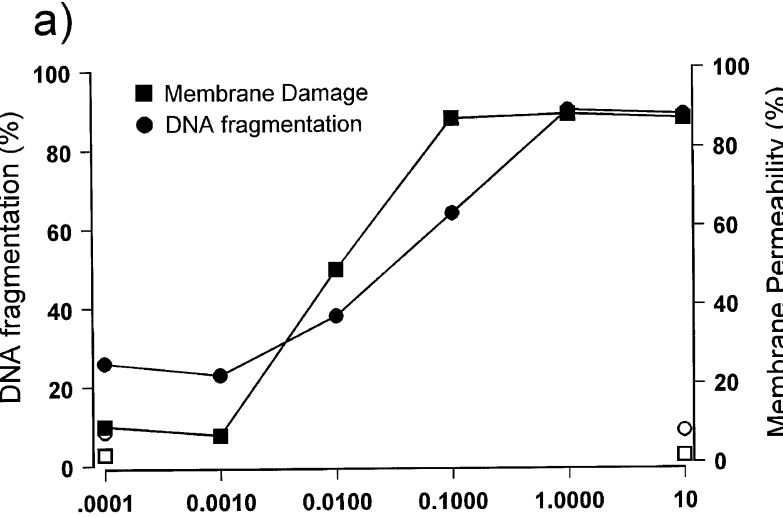

[C8] $(\mu \mathrm{g} / \mathrm{ml})$

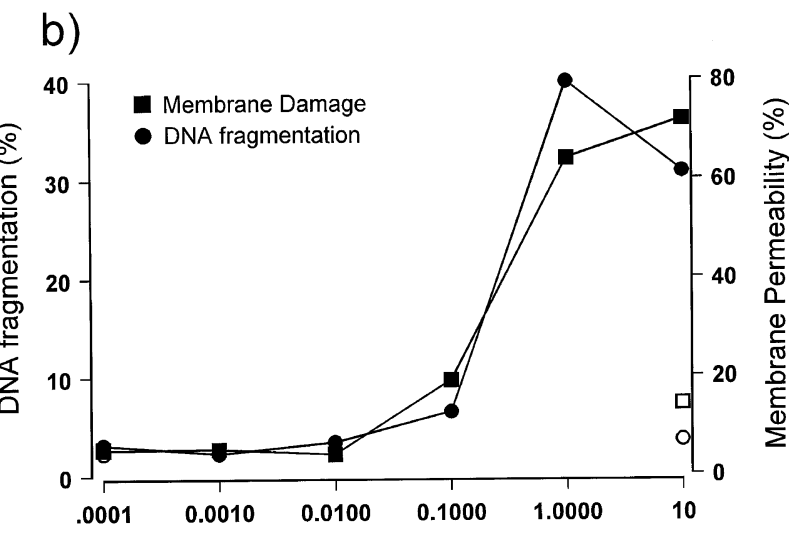

[C8] $(\mu \mathrm{g} / \mathrm{ml})$

Figure 3 Dependence of $\mathrm{C}$ lysis and DNA fragmentation on C8 protein. $\lg G$ was added to EHRB (a) or Raji (b) cells for $30 \mathrm{~min}$ at room temperature, prior to the addition of C8-deficient serum (30\%) reconstituted with varying levels of C8 protein. The extent of membrane permeability was determined by the $\mathrm{PI}$ assay (squares) after $1 \mathrm{~h}$. DNA fragmentation was then determined $18 \mathrm{~h}$ after addition of serum by the hypotonic PI assay, shown as circle symbols. Open symbols represent control samples and filled symbols represent results following addition of $\lg G$

subsequent DNA fragmentation, but that the membrane permeability alone is not sufficient and that once cells are damaged, it is the concentration of serum which determines the degree of DNA fragmentation. In addition, these data demonstrate that at levels of serum typically used by other workers (e.g. $<20 \%$ ) only low levels of DNA fragmentation were seen with Daudi and Raji cells, whilst at more physiological concentrations of serum ( $>20 \%$ ), there was extensive DNA fragmentation. This perhaps explains why these observations have not been reported previously.

To assess whether the observed DNA fragmentation was apoptotic in nature, agarose gel analysis was performed. These data, shown in Figure 5 for Daudi cells, revealed that the DNA fragmentation induced was oligonucleosomal in nature and displayed discrete banded DNA ladder patterns typical of apoptosis. ${ }^{2,7,8}$ Bands on the gels were approximately 180-200 base-pairs apart, indicating their nucleosomal origins. In addition, the
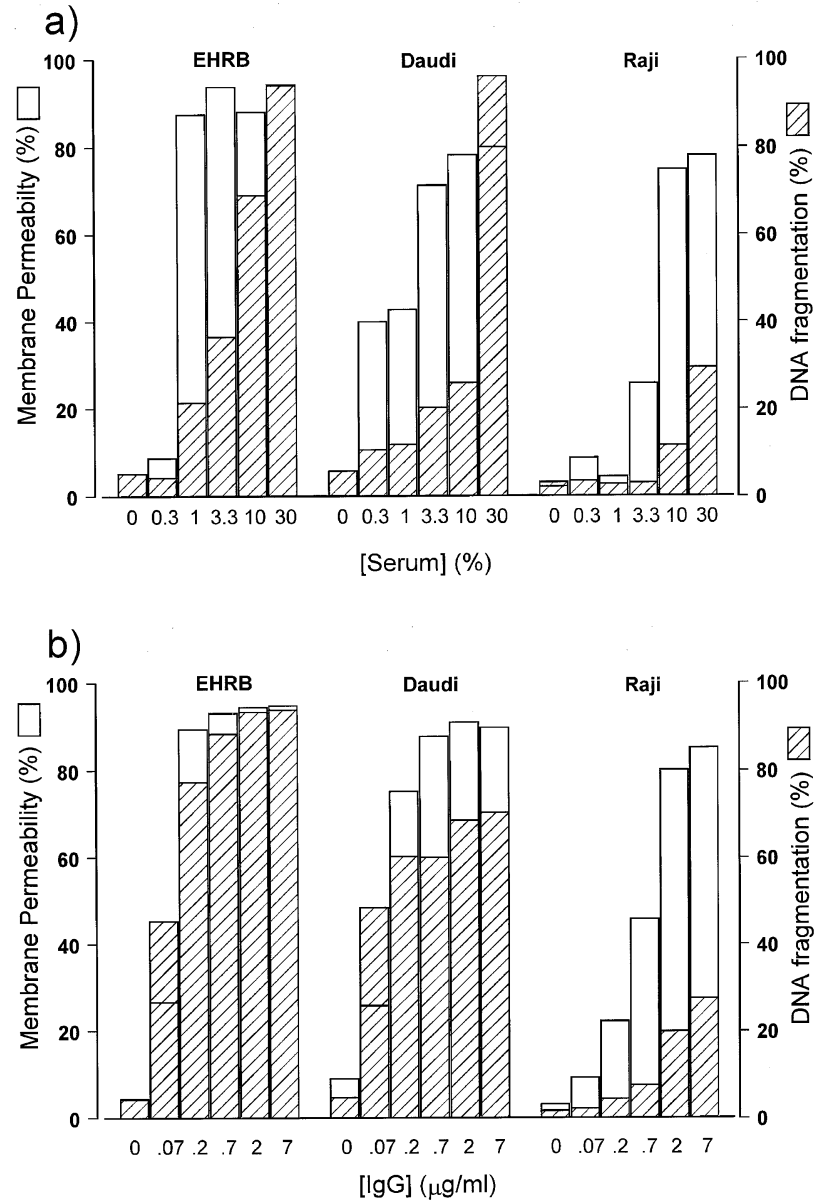

Figure 4 Dependence of DNA fragmentation on serum $(\mathbf{a})$ and $A b(\mathbf{b})$ concentration. In (a), IgG $(7 \mu \mathrm{g} / \mathrm{ml})$ was added to Raji, Daudi, or EHRB cells, allowed to bind for $30 \mathrm{~min}$ at room temperature and varying concentrations of serum added. In (b), varying concentrations of IgG were added to a constant concentration of serum $(20 \%)$. The degree of membrane permeability was determined by the PI assay after $30 \mathrm{~min}$, represented as unshaded bars. The extent of DNA fragmentation was assessed via the hypotonic PI assay 18$24 \mathrm{~h}$ after the addition of serum, shown as shaded bars

analysis supported the idea that fragmentation was a function of serum concentration, as increasing DNA fragmentation was observed with increasing levels of serum.

In the experiments detailed above, DNA fragmentation was detected after an overnight $(18-24 \mathrm{~h})$ incubation. In order to determine how soon after $C$ attack the target cell DNA was degraded, the TUNEL technique was employed. This technique is a sensitive method for distinguishing apoptotic and necrotic cell death. ${ }^{18}$ TUNEL analysis (Figure 6) revealed that $\mathrm{C}$-induced DNA fragmentation was due to the induction of apoptotic-like strand breaks. TUNEL positivity was observed as rapidly as $30 \mathrm{~min}$ after addition of serum (Figure 6b) and was evident at high levels after $1 \mathrm{~h}$. The extent of TUNEL positivity was found to be a function of serum concentration. Presumably, these strand breaks subsequently lead to the formation of the apoptotic DNA ladders, as DNA ladders were 


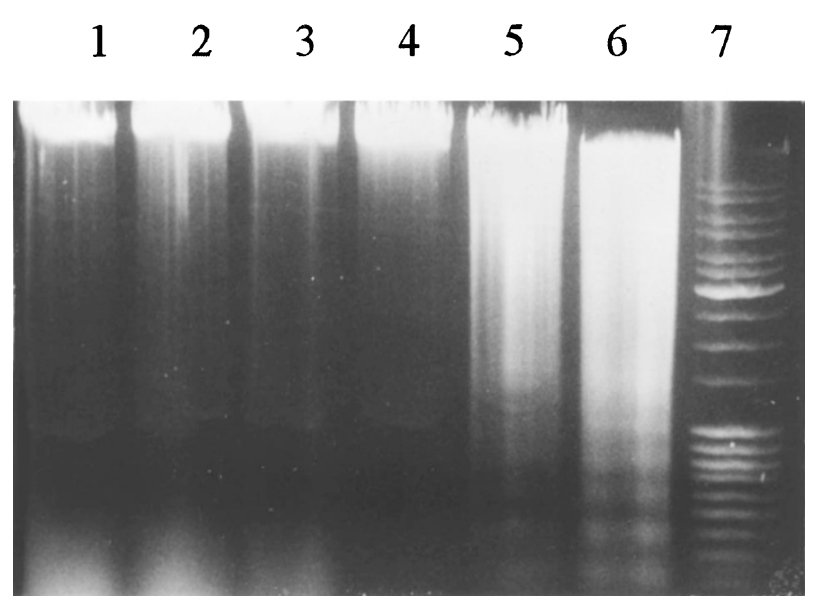

Figure 5 DNA fragmentation induced in Daudi cells after $C$ attack in varying levels of serum. $\operatorname{lgG}(7 \mu \mathrm{g} / \mathrm{ml})$ was added to $1-2 \times 10^{6}$ Daudi cells for $30 \mathrm{~min}$ at room temperature and then varying levels of serum added and the cells incubated for $18 \mathrm{~h}$ at $37^{\circ} \mathrm{C}$. Samples were then harvested, treated with Proteinase K, RNAse and subjected to agarose gel electrophoresis on a $1 \%$ gel for $2 \mathrm{~h}$. Untreated control cells are shown in lane 1. In lanes 2-6 increasing levels of serum $(1,3,10,20,30 \%)$ were added. A $100 \mathrm{bp}$ molecular weight ladder is shown in lane 7

observed as early as $2 \mathrm{~h}$ after the addition of serum (data not shown).

Given that apoptotic-like DNA fragmentation was apparent after $\mathrm{C}$ attack, we were intrigued to see whether any other features of apoptosis were evident. Electron microscopy (EM) revealed that following $C$ attack, cells in near-physiological concentrations of serum retained far greater plasma and nuclear membrane integrity than cells subjected to a similar level of attack in the presence of low levels of serum, shown for EHRB cells in Figure 7. Thirty minutes after $\mathrm{C}$ attack, cells in high concentrations of serum (Figure 7 panel c) have generally intact cell and nuclear membranes, whereas those in low levels of serum demonstrate discontinuity of the plasma membrane, celllysis and nuclear leakage (Figure 7 panel b). Furthermore a proportion of the cells in high levels of serum retained nuclear integrity for up to $6 \mathrm{~h}$ (data not shown).

Analysis of the EM data also demonstrated that chromatin was condensed following $C$ attack in the presence of high levels of serum, in a manner similar to that reported by Papadimitriou for Ehrlich cells. ${ }^{13}$ This observation, in conjunction with the DNA fragmentation data, demonstrates that features of apoptosis were apparent during C-mediated death of these cells. However, although cells attacked in high levels of serum were more resistant to complete lysis, signs of osmotic swelling and intracellular leakage were evident and ultimately many of the cells lysed completely. This was reflected by the general increase in cell size and by organelle swelling; two features associated with necrotic death. Furthermore, membrane blebbing, a common feature of apoptosis, was not evident. Clearly then, although some of the hallmark features of apoptosis are apparent during $\mathrm{C}$ mediated death, not all were present and many of the membrane and cytoplasmic events more closely resembled a necrotic
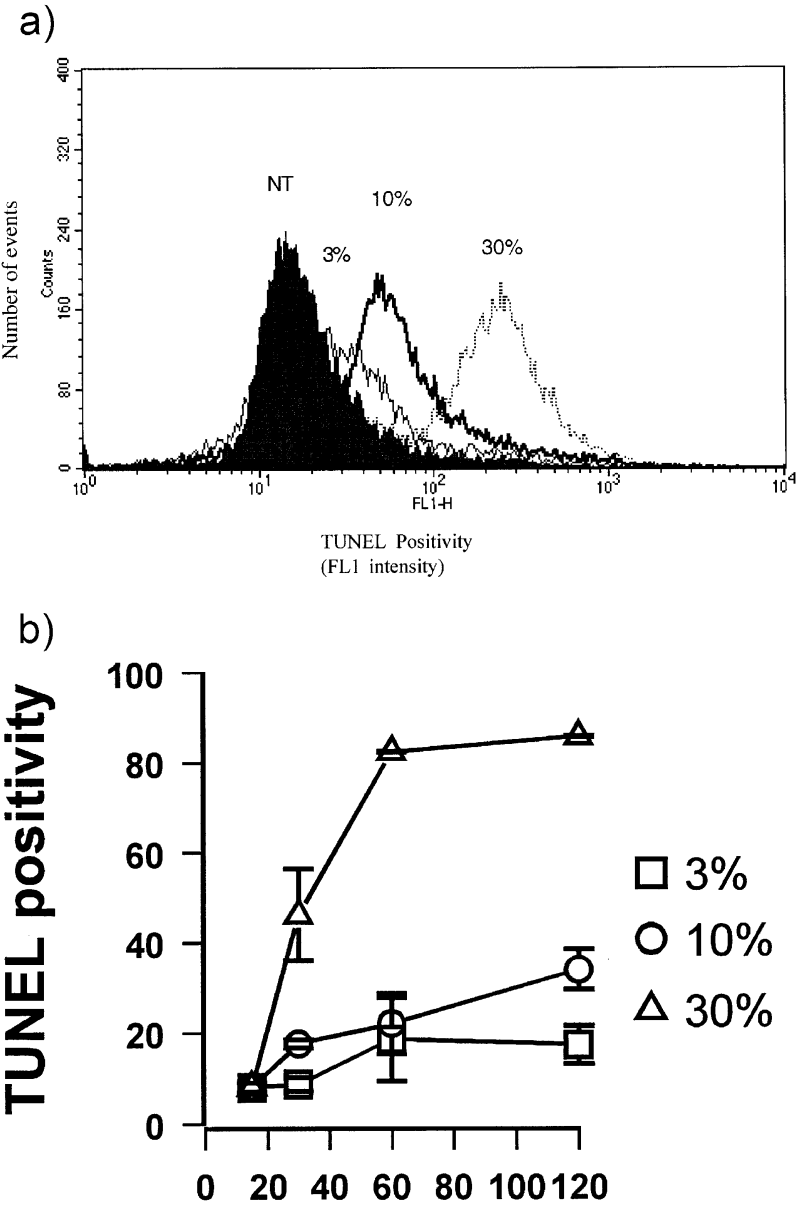

\section{Time (minutes)}

Figure 6 Assay of TUNEL positivity after C attack. EHRB cells were incubated with $\mathrm{lgG}(7 \mu \mathrm{g} / \mathrm{ml})$ for $30 \mathrm{~min}$ at $20^{\circ} \mathrm{C}$ and then varying levels of serum $(3,10$ or $30 \%)$ added and the cells incubated at $37^{\circ} \mathrm{C}$. The extent of DNA strand breakage was assessed after $10,30,60$ or 120 min via the TUNEL assay in (a). In (b) the means \pm S.D. of duplicate samples over the $2 \mathrm{~h}$ time course are shown. The histogram demonstrates the degree of TUNEL positivity after $1 \mathrm{~h}$

phenotype. Similar observations were made in all three cell lines examined.

Once the nature of the DNA fragmentation had been verified in these cells, we wished to identify the mechanism by which it was induced. $\mathrm{Ca}^{2+}$ ions rapidly enter target cells after $C$ attack $^{19,20}$ and have been suggested as one of the effectors of $\mathrm{C}$-induced cell death. ${ }^{21} \mathrm{Ca}^{2+}$ is also a known co-factor for certain apoptotic endonucleases. ${ }^{2,8,22,23,24}$ As serum contains high levels of $\mathrm{Ca}^{2+}(1.1-1.23 \mathrm{mM})^{25}$ it was suggested that the serum concentration dependence for DNA fragmentation was due to differences in the concentration of $\mathrm{Ca}^{2+}$ present in the different levels of serum. To determine if this was the case, low levels of serum were supplemented with increasing levels of exogenous $\mathrm{Ca}^{2+}$ ions and assessed for their ability to induce DNA fragmentation (Figure 8a). Ramos-EHRB cells were used in these experiments, as in this cell line low 
A

a

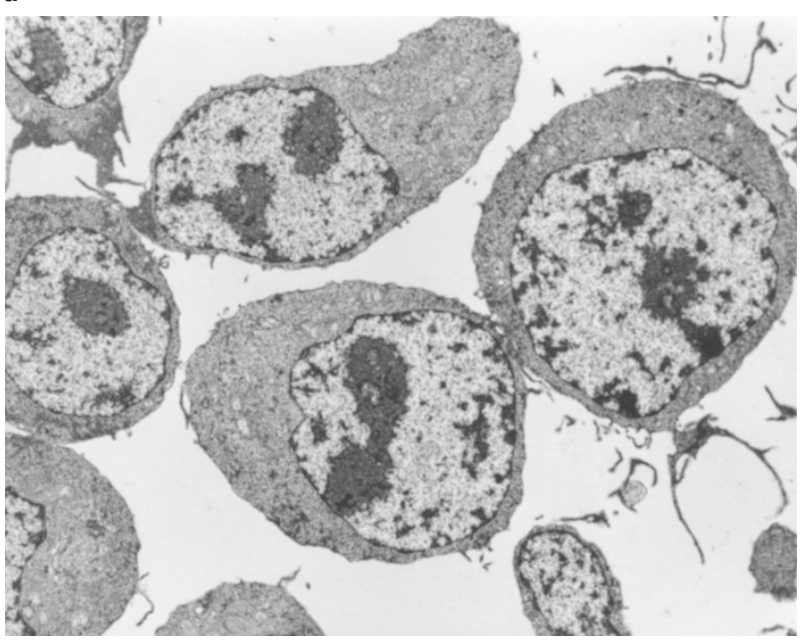

b

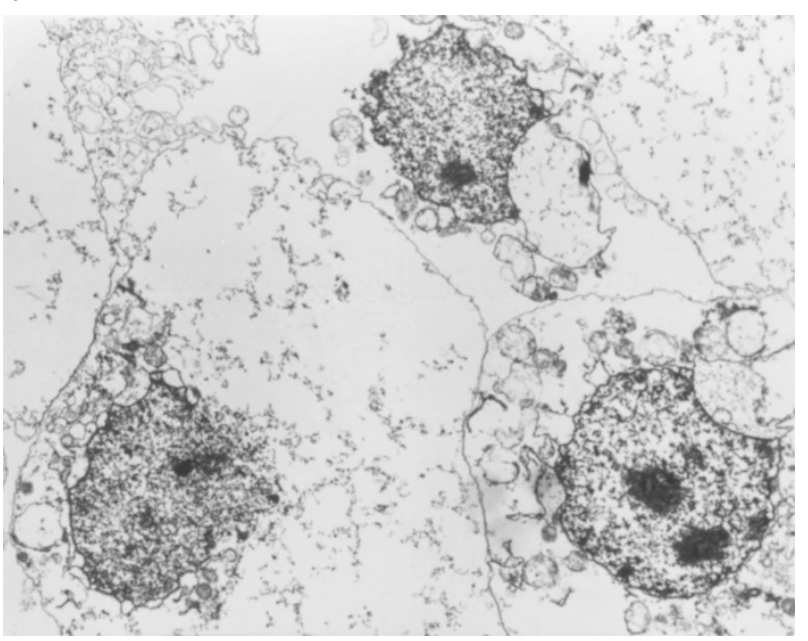

c

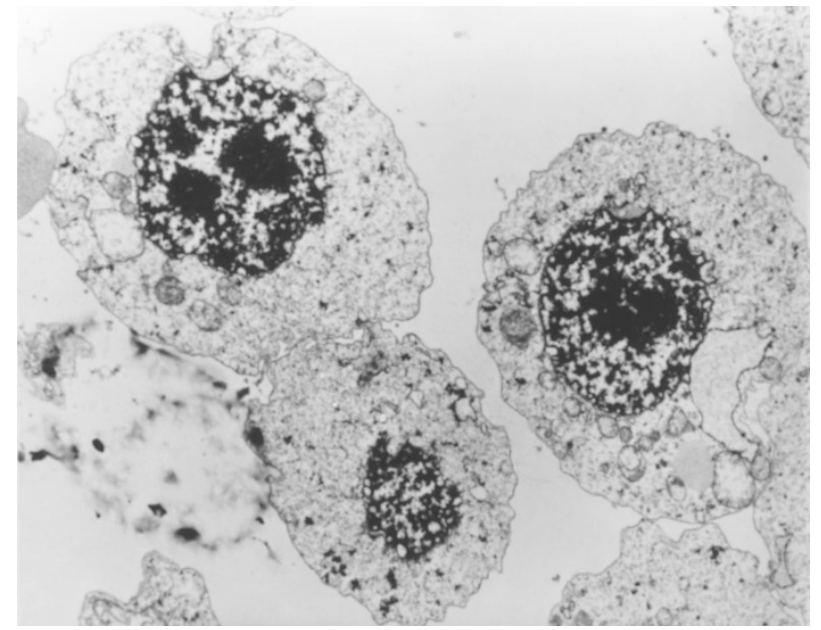

B

a

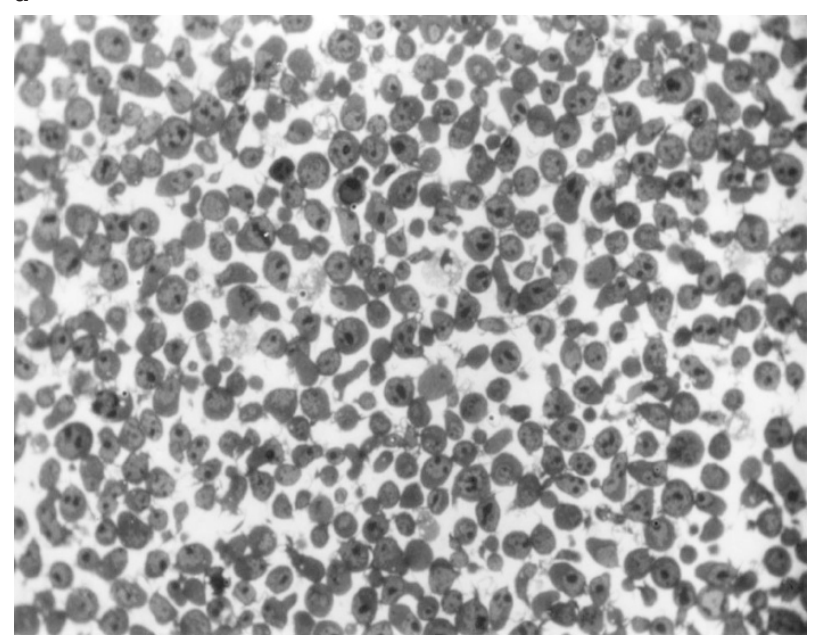

b

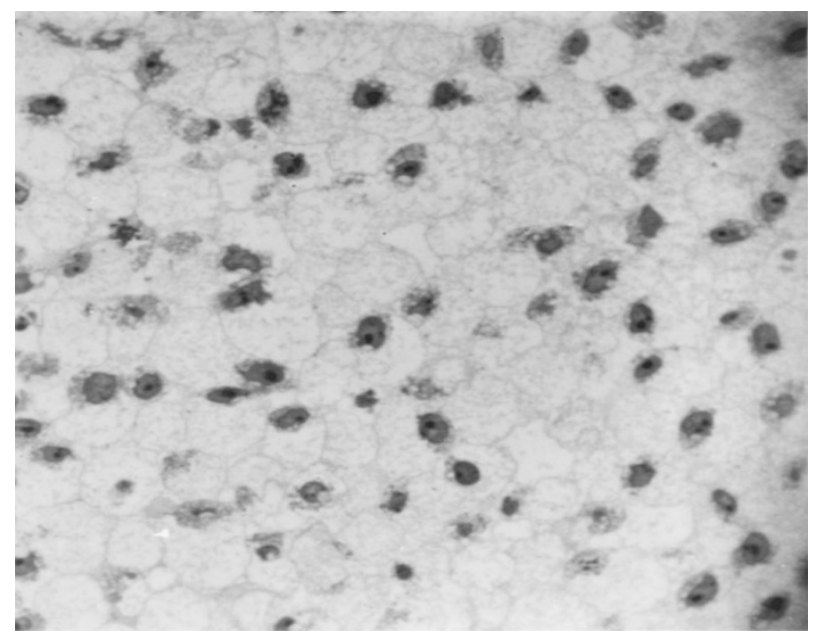

c

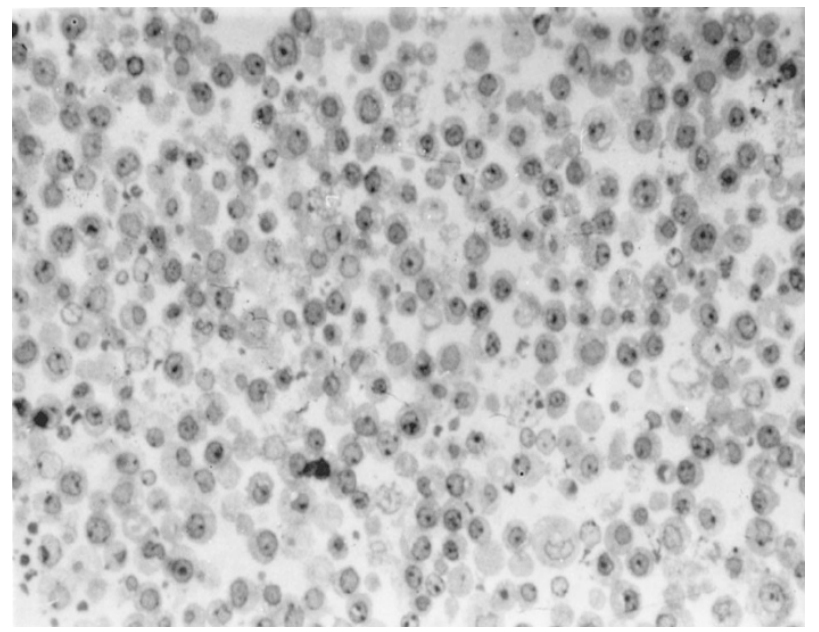

Figure 7 Light and electron microscopy of $C$ attacked EHRB cells in the presence of high (30\%) or low (3\%) levels of serum. EHRB cells were incubated with IgG $(7 \mu \mathrm{g} / \mathrm{ml})$ for $30 \mathrm{~min}$ at $20^{\circ} \mathrm{C}$ and then either 3 or $30 \%$ serum was added. After $30 \mathrm{~min}$ at $37^{\circ} \mathrm{C}$ the cells were harvested, fixed by adding glutaraldehyde $(1.5 \%$ final), washed and embedded in epon resin. For EM, thin $(90 \mathrm{~nm})$ sections were cut and stained with lead citrate. The views illustrated were gained at a magnification of $7500 \times$ and are shown in (A). In this figure, (a) represents normal untreated EHRB cells, (b) represents EHRB cells lysed in $3 \%$ serum and (c) represents cells attacked in $30 \%$ serum. For light microscopy, thick $(0.5 \mu \mathrm{m})$ sections were cut and stained with toluene blue as shown in (B). Again, (a) represents normal untreated EHRB cells, (b) represents EHRB cells lysed in 3\% serum and (c) represents cells attacked in $30 \%$ serum 
a)

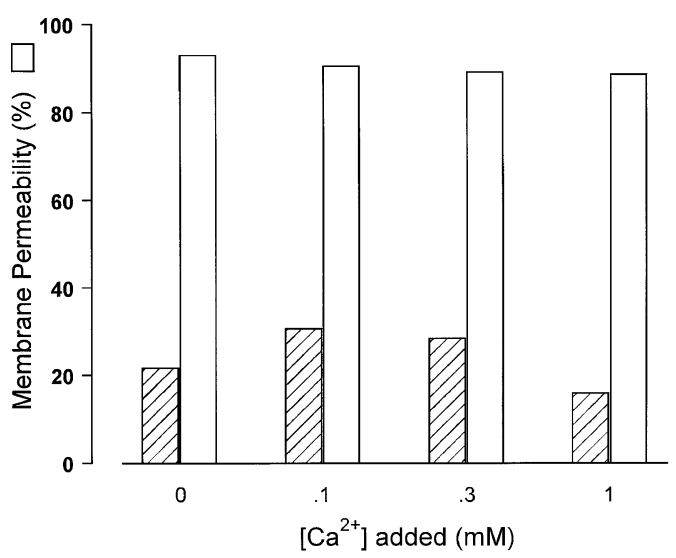

c)
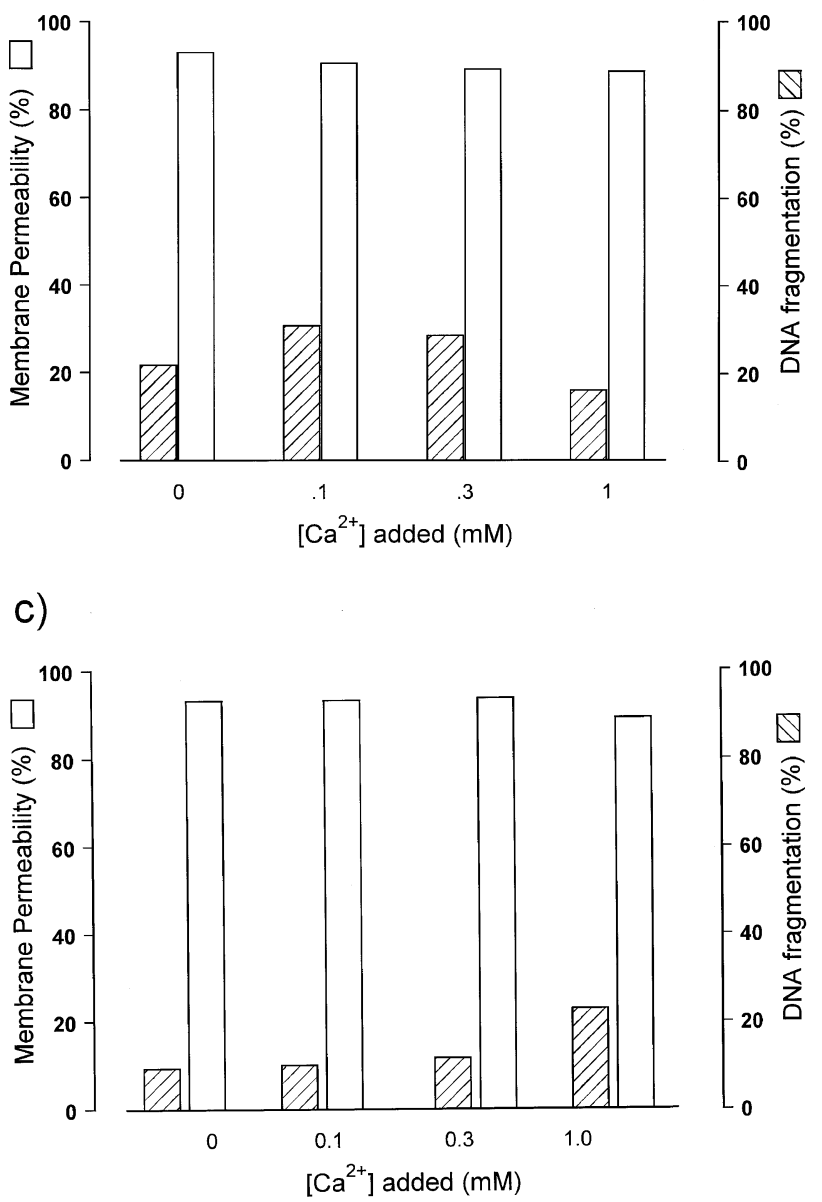

b)

d)
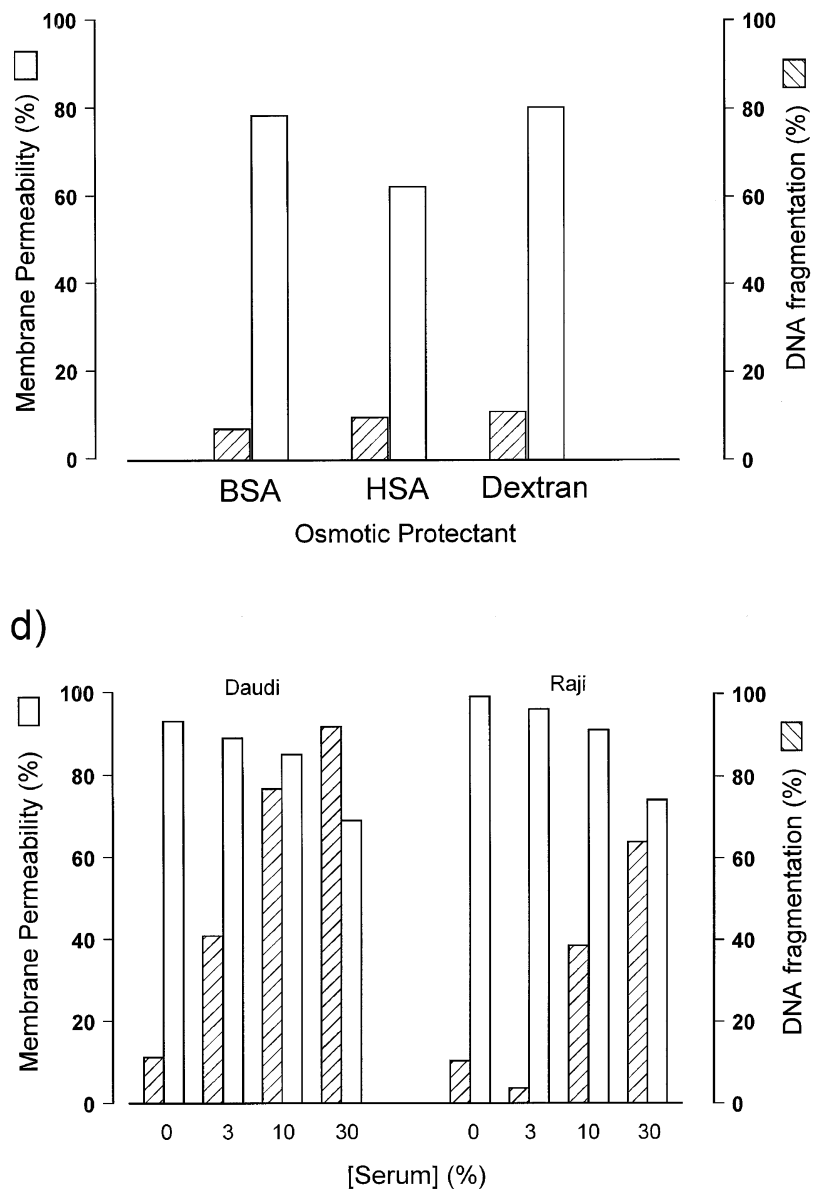

Figure 8 Effect of additional $\mathrm{Ca}^{2+}$, osmotic protection or melittin on the extent of DNA fragmentation. In (a-c), EHRB cells were lysed in the presence of IgG $\left(7 \mu \mathrm{g} / \mathrm{ml}\right.$ ) and $3 \%$ serum with (a) varying concentrations of exogenous $\mathrm{Ca}^{2+}$, (b) different osmotic protectants (dextran was added to a final concentration of $0.66 \mathrm{mM}$, and HSA and BSA were used at $30 \%$ ), or (c) varying concentrations of exogenous $\mathrm{Ca}^{2+}$ and $0.33 \mathrm{mM}$ dextran, added to the cultures. In (d), Raji or Daudi cells were incubated with melittin $(5-20 \mu \mathrm{g} / \mathrm{ml})$ in various doses of serum without lgG. Membrane permeability was determined $1 \mathrm{~h}$ after addition of serum; shown as open bars. DNA fragmentation was assessed $18 \mathrm{~h}$ after the addition of serum; shown as shaded bars

levels of serum are sufficient to induce maximal levels of membrane permeability, without concurrently high levels of DNA fragmentation, enabling us to separate the phenomenon of cell lysis and DNA fragmentation. As shown in Figure $8 \mathrm{a}$, low levels of serum supplemented with exogenous $\mathrm{Ca}^{2+}$ did not increase the DNA fragmentation observed.

Alternatively, differences between the effects of high and low levels of serum might be explained on a basis of osmotic potential. Within this rationale, it was proposed that the osmotic protection afforded by high levels of serum would enable cells to survive long enough for intracellular endonucleases to become activated (possibly by the $\mathrm{Ca}^{2+}$ influx) and instigate DNA fragmentation. In contrast, low levels of serum would not inhibit osmotic swelling and cell lysis would occur prior to DNA fragmentation. To investigate this possibility, low levels of serum were supplemented with dextran, Human serum albumin (HSA) or Bovine serum albumin (BSA), to provide equivalent osmotic protection to that afforded by high levels of serum. These experiments, represented in Figure 8b, demonstrate that $\mathrm{C}$ attacked cells, in the presence of osmotic protectants, though protected from complete lysis, do not undergo significant DNA fragmentation in the absence of sufficiently high levels of serum. Next we investigated whether both osmotic protection and high levels of $\mathrm{Ca}^{2+}$ ions were sufficient to initiate DNA fragmentation (Figure 8c). These experiments, using dextran as the osmotic protectant, revealed that osmotically protected cells undergoing $C$ attack in the presence of elevated levels of $\mathrm{Ca}^{2+}$ still did not undergo significant DNA fragmentation in the absence of high levels of serum.

To ascertain whether other forms of membrane permeability could induce DNA fragmentation, the bee venom derived pore-forming polypeptide melittin was used. DNA fragmentation was not observed following treatment with melittin in the absence of serum, although membrane permeability was induced (as measured by PI permeability). When serum was included (without $A b$ to 


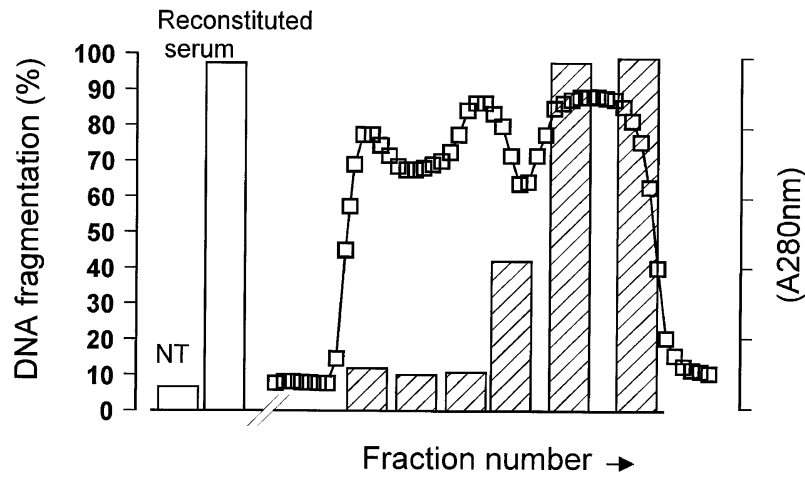

Figure 9 DNA fragmentation induced by various fractions of serum following separation on ACA44. Human serum was added to a pre-equilibrated ACA44 column and fractions collected. The approximate molecular weight of proteins in the different fractions was then determined by comparison with the elution profile of known molecular weight standards. $10 \%$ ( $\mathrm{v} / \mathrm{v}$ final) of fractionated serum was added to $3 \%$ native serum (to ensure membrane permeabilisation) and the DNA fragmentation activity of each fraction was determined using the hypotonic $\mathrm{PI}$ assay assessed $16 \mathrm{~h}$ after addition of serum. Also shown are the levels of DNA fragmentation induced with serum reconstituted from equivalent portions of the fractionated serum in the absence (NT) or presence of $A b$

activate C), DNA fragmentation was observed and in a dose-dependent manner. Furthermore, heat-inactivated serum was also able to induce DNA fragmentation in these experiments (data not shown) excluding the possibility that $C$ activation is necessary. Together these data demonstrated that the DNA fragmentation induced was dependent upon a property of serum that was not related to osmotic potential, $\mathrm{Ca}^{2+}$ concentration or $\mathrm{C}$ activation.

In view of these results, we decided to fractionate the components of serum and determine if the DNA fragmenting activity could be restricted to molecules of a given size. Fractionation was carried out using an ACA44 gel matrix. As illustrated in Figure 9, the major DNA fragmenting activity was found to be restricted to fractions corresponding to proteins of approximately $25-50 \mathrm{kDa}$ in size. Fractionation of animal sera (guinea pig, sheep, rabbit) yielded similar results (data not shown), indicating that a similar factor is involved. Intriguingly, DNase I is $32-$ $38 \mathrm{kDa}^{26,27}$ and furthermore, is the only well known serum endonuclease. ${ }^{23,27,28,41}$

To further characterise the nature of the DNA fragmentation-factor in serum, we undertook a series of inhibition studies. The data from these experiments (Figure 10) demonstrate that EGTA, EDTA, and $\mathrm{Zn}^{2+}$ ions were capable of inhibiting the DNase activity in serum, but that aurintricarboxylic acid (ATA) was not. This inhibitor profile is similar to that of serum DNase $I^{26}$ To eliminate the possibility of a cytosolic DNase being involved during the death process, we isolated nuclei from the cells and repeated these studies. Similar results were achieved with isolated nuclei as in whole cells, such that DNA fragmentation was dependent on serum concentration, inhibited by EGTA/EDTA and $\mathrm{Zn}^{2+}$ and not by ATA (data not shown). Finally, to examine whether caspases were involved in the DNA fragmentation, three tetrapeptide a)

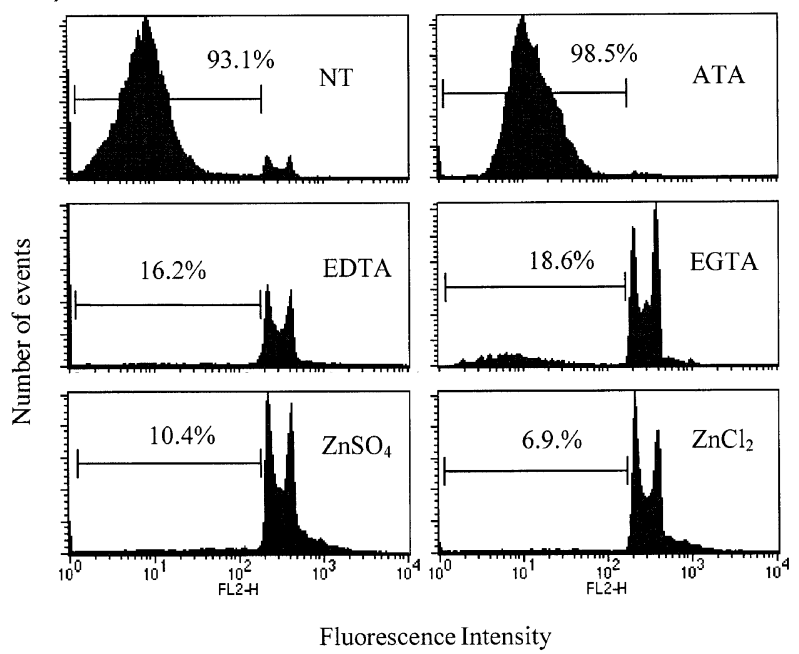

b)

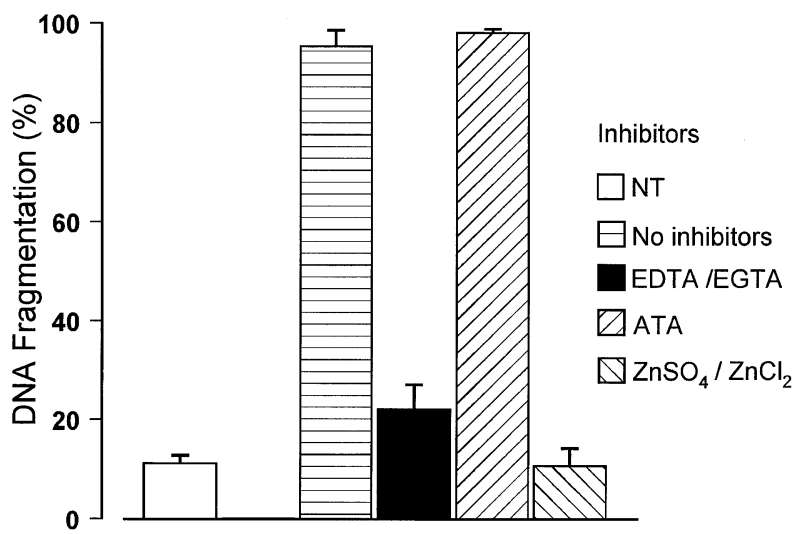

Figure 10 Inhibitor profile of DNase activity following $C$ attack of EHRB cells in $30 \%$ serum. Following $C$ attack for $15 \mathrm{~min}$ at $37^{\circ} \mathrm{C}$ to allow maximal membrane permeability, various endonuclease inhibitors were added to the samples. In a series of experiments $1-5 \mathrm{mM}$ final concentrations of $\mathrm{ZnCl}_{2}$, $\mathrm{ZnSO}_{4}, \mathrm{EGTA}$, EDTA or ATA were used. Shown in (a) is an example of a typical set of results. In (b) two identical experiments are compared with the means shown

caspase inhibitors (YVAD, ZVAD and DEVD) were used. All three inhibitors were ineffective even when applied at a concentration of $250 \mu \mathrm{M}$, implying that caspases are not involved in this process (data not shown). All of these data indicate that the DNA fragmentation which follows $C$ attack is due to an extracellular endonuclease which is present in serum and that this endonuclease is likely to be DNase I.

\section{Discussion}

We have shown that following $C$ attack, various cell lines underwent an extensive and rapid apoptotic-like DNA fragmentation, which was dependent on high levels of serum. The DNA fragmentation was not seen in low levels of serum. However, low levels of serum $(1-10 \%)$ were able to induce substantial membrane permeability. Titration experiments with C8-depleted serum and C8 protein confirmed that 
functional $\mathrm{C}$ was necessary for DNA fragmentation to occur and, more importantly, demonstrated that MAC formation was vital for the induction of DNA fragmentation. Subsequent experiments revealed that melittin pores could substitute for MAC in inducing membrane permeability, although high doses of serum were again necessary for the induction of DNA fragmentation. The requirement for high doses of serum in both of these systems indicated that DNA fragmentation was dependent upon a titratable factor. Furthermore, as isolated nuclei were similarly susceptible to the effects of high levels of serum (data not shown) this indicated that cytosolic endonucleases did not play an important role in the fragmentation process. Lack of a requirement for the cytosol also indicated that caspases were not involved in this process and this was supported by the fact that the tetrapeptides YVAD, ZVAD and DEVD did not inhibit the observed DNA fragmentation (data not shown).

The effects of high serum levels could not be mimicked by osmotic protectants either alone or in conjunction with elevated levels of $\mathrm{Ca}^{2+}$, indicating that the DNA fragmentation which occurred was not simply due to an influx of $\mathrm{Ca}^{2+}$ and activation of a nuclear-based $\mathrm{Ca}^{2+}$ dependent endonuclease such as that described by Wyllie. ${ }^{24}$ However, once initiated, it is possible that endogenous, cytosolic and nuclear endonucleases would become activated. In the absence of cytosolic and nuclear endonucleases, it must be supposed that the DNA fragmentation following $C$ attack is due to the entry of an external DNase present in serum.

One possible source of external endonucleases would be mycoplasma infected cells, which have been shown to be capable of secreting endonucleases capable of inducing internucleosomal DNA fragmentation. ${ }^{29}$ However, in our study the cell lines used were routinely screened for mycoplasma and found to be uninfected. The FCS used in cell culture is screened for mycoplasma infection and can similarly be disregarded as a source of mycoplasmaderived external endonucleases.

DNase activity in serum and plasma has long been reported for a plethora of species, including rat, ${ }^{30}$ mouse 23,31 and human. ${ }^{27,28,32}$ Various authors have investigated the nature of this serum DNase ${ }^{27,28,32}$ and although its origin is unclear, it would appear that the major endonuclease activity is due to isoforms of DNase $1 .{ }^{27}$ In support of this suggestion, Polzar and Mannherz ${ }^{33}$ have identified a potential signal peptide in the rat DNase I gene, which would readily facilitate its secretion allowing its entry into the serum.

In addition to its role as the main endonuclease in serum, several groups have suggested that DNase I is the central endonuclease involved in apoptotic cell death ${ }^{2,26}$ and prior to the discovery of Caspase Activated DNase (CAD) in $1998,{ }^{34}$ provided a number of convincing lines of evidence in support of this. However, one hurdle that proponents of DNase I face is that it is found predominantly within the endoplasmic reticulum (ER) and for DNA fragmentation to occur it must enter the nucleus. How it might do this is uncertain, although the rise in calcium seen during apoptosis has been suggested as a potential mechanism, ${ }^{26}$ as $\mathrm{Ca}^{2+}$ fluxes have been reported to induce dissolution of the ER and hence perturbation of the perinuclear membrane. ${ }^{35}$

Intriguingly, C attack also induces a rise in cytoplasmic calcium. ${ }^{19,20}$ Could it be that the endonuclease responsible for fragmentation of target cell DNA following $C$ attack is also DNase I? Our study shows that fragmentation of the nuclear DNA occurs at neutral $\mathrm{pH}$ and is potently inhibited by $\mathrm{Zn}^{2+}$ ions, chelating agents EDTA and EGTA, but not ATA, an inhibitor profile which closely matches that reported for serum DNase I. ${ }^{26}$ In addition, DNase $I$ is the only well known serum endonuclease $e^{23,27,28,41}$ and our fractionation data indicate that a protein of its size (32$38 \mathrm{kDa}$ ) is involved in this process. Furthermore, it has been established by Peitsch et al, that DNase I is capable of oligonucleosomal apoptotic DNA fragmentation in the presence of serum. ${ }^{23}$ For these reasons, we hypothesise that the observed DNA fragmentation of $C$ attacked cells is a direct result of serum DNase and that this DNase is either DNase I, or a close homolog. Endogenous, intracellular DNase I may contribute to the DNA degradation in the manner suggested by Peitsch et $a l^{23,26}$ but our data indicate a requirement for the external DNase present in serum. Moreover, we have recently carried out experiments that show that when increasing concentrations of purified DNase I are titrated into low (but lytic) levels of serum, a corresponding increase in DNA fragmentation is seen (data not shown). Ongoing work will attempt to define the nature of the external DNase more precisely.

Our proposed model then, for $\mathrm{C}$ attack of cells under near-physiological conditions, is as follows. Firstly, C5b-9 lesions are punched into the cell membrane allowing influx of small protein molecules, such as the serum DNase. Subsequently, the internalised DNase appears to access and degrade the target cell DNA. This process appears similar to that used by cytotoxic cells to kill their targets. During CTL- and NK-cell killing, cytotoxic granules are released which deliver perforin and granzymes to the target cell. Perforin forms pores in the target cell membrane, which facilitates the entry and activity of the granzymes. ${ }^{36}$ The granzymes then initiate the caspase cascades present within the target cell, which result in apoptosis and fragmentation of the resident DNA. Given this resemblance, it is intriguing to discover that perforin has substantial homology to the terminal component of $\mathrm{C}$, C9. ${ }^{37}$ Furthermore, it is possible that defensins may operate similarly, given that they also are able to disrupt membrane integrity. ${ }^{38}$

One of the central predictions from our hypothesis is that all membrane damaging events should lead to similar modes of cell death. The preliminary results with the membrane pore forming polypeptide, melittin, seem to support this idea. Exposure to melittin in the presence of serum results in potent DNA fragmentation, in a dosedependent manner similar to that reported here for $\mathrm{C}$ damage and in a range of cells including mouse LTK fibroblasts, Chinese Hamster Ovary cells and EBVtransformed B-cells (data not shown), as well as the lymphoma lines (Figure 8d). Membrane permeability induced with melittin in the absence of serum yields no observable DNA fragmentation, even in the presence of 
osmotic protectants and elevated levels of $\mathrm{Ca}^{2+}$, similar to $C$ attack in low levels of serum (data not shown). If apoptotic DNA fragmentation is commonly seen following any form of membrane permeability, this has great relevance for the study of apoptosis both in vitro and in particular in vivo. In in vitro experiments, membrane damaging agents, such as residual $\mathrm{C}$ activity and perforin, may result in false detection of apoptotic death by DNA fragmentation criteria. Indeed, we have observed just such a phenomenon in the sensitive cell line RamosEHRB cultured in $10 \%$ non heat-inactivated FCS which contained enough residual $\mathrm{C}$ to facilitate lysis and DNA fragmentation with certain mAb (data not shown). This concern is even more relevant in vivo, where $C$ and DNase activity will be maximal in circulating plasma. For this reason, criteria other than DNA fragmentation may have to be utilised to define apoptosis in vivo, or more likely a number of such criteria used in conjunction, as suggested by Kerr et al. ${ }^{39}$

Although we have demonstrated that the cellular integrity maintained following $\mathrm{C}$ attack in high concentrations of serum is not an important factor in initiating subsequent DNA fragmentation, its role in the death process should not be ignored. Under conditions of high serum, the external environment is at relatively high osmolarity and helps to prevent total cell lysis, allowing the cell to retain its integrity, particularly nuclear, for a longer period of time. These conditions mimic those seen in vivo more closely than those used in previous studies and the delay in lysis and retention of the nuclear material may be extremely important when considering $\mathrm{C}$ mediated death in vivo, since it should allow the DNA to be fragmented before its release into the surrounding environment.

In a multicellular organism, cells are targeted for death when they are either unwanted, infected or neoplastic. Therefore, maintaining nuclear integrity of a dying cell for a longer period of time allowing time for DNA to be degraded helps to prevent exposure of surrounding cells to potentially neoplastic or foreign DNA. The protection of neighbouring cells from so-called dangerous DNA has been suggested as the main role of the endonuclease during apoptosis. ${ }^{8}$ It seems that the serum DNase is well adapted for this role in several ways. Firstly, the singlestrand breaks induced by the serum DNase halt transcription, thereby rendering any dangerous DNA transcriptionally inactive. ${ }^{40}$ Secondly, the induction of strand-breaks into target cell DNA facilitates phagocytic activity in neighbouring cells. In addition to aiding the clearance of potentially dangerous and immunogenic DNA, this function may also serve to prevent inflammation and subsequent auto-Ab generation. ${ }^{26}$ In particular, preventing chromatin, a highly immunogenic protein implicated in development of auto-immune disorders such as SLE, getting into the circulation may be important. It is interesting to note that SLE patients display diminished levels of DNase in their serum, ${ }^{41}$ perhaps implying that serum DNase may play a role in degrading DNA in serum and preventing auto-immune reactions from developing. Thirdly, DNA fragmentation prevents surrounding cells from having to cope with the huge volume of unpackaged genomic DNA which would be released after death.

All of these facets of DNA fragmentation are geared to reduce inflammation and remove potential immunogens: the primary goals of apoptosis. In recent years it has become apparent that the components of $C$ link quite closely with those of apoptosis, certainly more so than was envisaged as little as 5 years ago. A spate of recent papers have demonstrated that $\mathrm{C}$ may be involved in the removal of apoptotic cells through tagging for phagocytosis via C1q or C3b fragments. ${ }^{42-44}$

In conclusion, this work demonstrates that $\mathrm{C}$ attack of mammalian cells can result in apoptotic-like condensation and fragmentation of nuclear DNA, which appears to arise from the influx of a serum DNase, which may be DNase I. These data contribute to the idea that $\mathrm{C}$-induced death is not entirely necrotic in nature but may instead resemble a more rapid form of apoptosis which demonstrates certain necrotic-like cytosolic and membrane features. Furthermore, these data imply that other forms of membrane damage may also induce apoptotic-like cell death in vivo.

\section{Materials and Methods}

\section{Materials}

Daudi, Ramos, Ramos-EHRB, Raji, and Namalwa cells were all obtained from the European Collection of Cell Cultures (ECACC) and were maintained in RPMI-1640 medium supplemented with antibiotics and $10 \% \mathrm{FCS}$ at $37^{\circ} \mathrm{C}$ in a $5 \% \mathrm{CO}_{2}$ humidified incubator. Cells were maintained in log phase of growth for $24 \mathrm{~h}$ prior to experiments. WW2, EBV immortalised B-cells were a kind gift from Myf Spellerberg, HIT group, Southampton University Hospital. The sensitivity of these cell lines to $C$ mediated cell lysis was directly related to the levels of $C$ control proteins (CD55 and CD59) expressed at the cell surface (data not shown).

Serum from all species was prepared as follows: whole blood was allowed to clot at room temperature for 30-60 min. Serum was then collected and centrifuged at $900 \times g$ for $20 \mathrm{~min}$. Serum was stored at $-80^{\circ} \mathrm{C}$. For experiments, $100 \%$ serum was taken to be the undiluted soluble fraction remaining after clotting. C8 depleted human serum and human $\mathrm{C} 8$ protein were generated and prepared as described previously. ${ }^{45}$ All human serum used in this study was from AB donors, although analogous results were achieved with serum from other donors (data not shown). Heat-inactivation of serum was carried out at $56^{\circ} \mathrm{C}$ for $30 \mathrm{~min}$.

The Ab used for activation of the classical $C$ pathway was antiCD20 mAb $\left[\mathrm{IF5} ;{ }^{46}\right]$, although similar results were achieved with the IgG fraction of rabbit anti-serum raised against human tonsil cells. The hybridoma line secreting IF5 was expanded in tissue culture and purified from culture supernatant using a Protein $A$ column as detailed by Glennie et $a l .{ }^{47} \mathrm{~F}\left(\mathrm{ab}^{\prime}\right)_{2}$ fragments of IgG were prepared by limited proteolysis with pepsin at $\mathrm{pH} 4.0-4.2$ as detailed by Glennie et al. ${ }^{47}$ BSA (fraction V, $65000 \mathrm{mw}$ ) was obtained from Wilfred Smith Ltd, Middlesex. HSA was obtained from BPL, Elstree, Herts. Dextran (65$85000 \mathrm{mw}$ ) and melittin were purchased from Sigma, Poole, Dorset.

\section{Electron microscopy (EM)}

EM was performed using a protocol similar to that described by Papadimitriou et al. ${ }^{13}$ Briefly, after $30 \mathrm{~min}$ in serum, cells were fixed in the presence of their incubation media by the addition of an equal 
volume of $3 \%$ glutaraldehyde in $0.1 \mathrm{M}$ sodium cacodylate buffer $\mathrm{pH} 7.4$ for $2 \mathrm{~h}$ at room temperature. Cells were then washed several times in cacodylate buffer. Post-fixation with osmium was followed by en bloc staining with uranyl acetate before dehydration via graded alcohols and embedding in epon resin. Thick $(0.5 \mu \mathrm{M})$ and thin $(90 \mathrm{nM})$ sections were then cut, stained with toluene blue or lead citrate and viewed via light and electron microscopes respectively. EM was performed on a Hitachi $\mathrm{H}-7000$.

\section{Flow cytometric analysis of DNA fragmentation using PI}

Samples were assessed rapidly for DNA fragmentation essentially as per the method of Nicoletti et al. ${ }^{17}$ Briefly, aliquots of cells (5$10 \times 10^{5}$ ) were centrifuged for $5 \mathrm{~min}$ at $500 \times g$ and then washed once in PBS. The cells were then resuspended in hypotonic fluorochrome solution $(50 \mu \mathrm{g} / \mathrm{ml} \mathrm{PI}, 0.1 \%(\mathrm{w} / \mathrm{v})$ sodium citrate, $0.1 \%(\mathrm{w} / \mathrm{v})$ Triton X100) and incubated in the dark at $4^{\circ} \mathrm{C}$ overnight or $1 \mathrm{~h}$ at room temperature. PI staining of DNA from 10000 cells was detected on a FACScan flow cytometer (Becton Dickinson) and the proportion of DNA giving fluorescence below the $\mathrm{G} 1 / 0$ peak was taken as a measure of apoptosis.

\section{Analysis of DNA fragmentation by agarose gel electrophoresis}

Following incubation of cells under appropriate conditions, samples containing $1-2 \times 10^{6}$ cells were harvested. Twenty $\mu$ I TE-SLS $(10 \mathrm{mM}$ EDTA, $50 \mathrm{mM}$ Tris $\mathrm{HCl} \mathrm{pH} 8.0,0.5 \%(\mathrm{v} / \mathrm{v})$ sodium lauryl sarkosinate (SLS, Sigma)) plus $0.5 \mathrm{mg} / \mathrm{ml}$ Proteinase K (Sigma) was then added, and the samples incubated for $1-2$ h at $50^{\circ} \mathrm{C}$. Ten $\mu \mathrm{l} 0.16 \mathrm{mg} / \mathrm{ml}$ RNase A (Sigma) was added and samples were incubated for a further 1-2 $\mathrm{h}$ at $50^{\circ} \mathrm{C}$. The temperature of the samples was then increased to $70^{\circ} \mathrm{C}$ for addition of $10 \mu$ l of loading buffer (10 mM EDTA, $1 \%$ (w/v) low melting point agarose, $0.25 \%(\mathrm{w} / \mathrm{v})$ bromophenol blue, $40 \%(\mathrm{w} / \mathrm{v})$ sucrose). Samples were loaded into dry wells of $1 \%(\mathrm{w} / \mathrm{v})$ agarose gels containing $0.5 \mathrm{mg} / \mathrm{ml}$ ethidium bromide and run either overnight at $30-40 \mathrm{~V}$ or for $2-3 \mathrm{~h}$ at $80 \mathrm{~V}$, in TAE $(89 \mathrm{mM}$ Tris, $89 \mathrm{mM}$ boric acid, $2 \mathrm{mM}$ EDTA, $\mathrm{pH}$ 8.4). DNA was visualised under UV light illumination.

\section{Nuclei extraction}

Nuclei were isolated using the method of Nieto et al. ${ }^{48}$ Briefly, RamosEHRB cells were washed twice in PBS and lysed in a hypotonic solution of $1.5 \mathrm{mM} \mathrm{MgCl}_{2}$ for 30 min on ice, releasing intact nuclei. Nuclei were then harvested by centrifugation for $5 \mathrm{~min}$ at $500 \times \mathrm{g}$ and washed twice in $1.5 \mathrm{mM} \mathrm{MgCl}_{2}$ before resuspension in a solution containing $10 \mathrm{mM}$ Tris (pH 7.5), $200 \mathrm{mM}$ sucrose and $60 \mathrm{mM} \mathrm{NaCl}$.

\section{Osmotic protection}

In osmotic protection experiments, dextran, HSA, or BSA were used. Dextran was used at concentrations between 0.33 and $1.33 \mathrm{mM}$. HSA and BSA were used at $10-30 \%(\mathrm{w} / \mathrm{v})$ final concentrations. These solutions allowed permeabilisation of the plasma membrane (as determined by PI entry) but delayed full cell lysis (as determined microscopically or via flow cytometry) and mimicked closely the osmotic protection effects of $30 \%$ human serum.

\section{Membrane permeability assay}

Membrane permeability was detected using a rapid and simple $\mathrm{PI}$ exclusion assay. Diminished membrane integrity facilitates entry of $\mathrm{PI}$ into cells where it binds DNA causing a large (1000-fold) increase in fluorescence in the red area of the spectrum. This assay was carried out by adding $100 \mu \mathrm{l}$ of PI solution (10 $\mu \mathrm{g} / \mathrm{ml}$ in PBS) to $150 \mu \mathrm{l}$ of a given cell sample. The mixture was then assessed immediately by FACS, using a $488 \mathrm{~nm}$ argon laser for excitation and a $560 \mathrm{~nm}$ dichroic mirror and $600 \mathrm{~nm}$ band pass filter (bandwidth $35 \mathrm{~nm}$ ) for detection. More traditional ${ }^{51} \mathrm{Cr}$ release assays gave comparable results (data not shown).

\section{Serum separation}

The protein components of human serum were separated on a basis of size using an ACA44 gel filtration column. ACA44 gel (IBF, France) was packed by gravity flow into two $640 \mathrm{ml}$ columns, which were connected in series and equilibrated with PBS. Human serum was then added to the column and run in PBS under pressure from gravity. Flow through was assessed by UV absorbance at $280 \mathrm{~nm}$ to detect protein. Minor fractions were collected, pooled into one of six major fractions, concentrated and adjusted back to the same volume as was loaded onto the column and subsequently assessed for DNA fragmentation activity. The approximate molecular weight of proteins in the different major fractions was then determined by comparison with the elution profile of known molecular weight standards.

\section{Acknowledgements}

The authors would like to thank Dr Andrew George and Dr Ruth French for careful reviewing of the manuscript. This work was funded by grants from Tenovus, Cardiff and The Wellcome Trust.

\section{References}

1. Kerr JFR, Wyllie AH and Currie AR (1972) Apoptosis: A basic biological phenomenon with wide-ranging implications in tissue kinetics. Br. J. Cancer. 26: $239-257$

2. Hughes MF and Cidlowski JA (1996) Enzymology of apoptosis. In Apoptosis in normal development and cancer, Sluyser M, ed (London: Taylor and Francis Press Ltd) pp. 20-31

3. Wyllie AH, Kerr JFR and Currie AR (1980) Cell Death: the significance of apoptosis. Intl. Rev. Cytol. 68: 251-306

4. Umansky SR (1996) Apoptosis: molecular and cellular mechanisms: A review. Mol. Biol. 30: 285-295

5. Kerr JFR, Winterford CM and Harmon BV (1994) Apoptosis: its significance in cancer and cancer therapy. Cancer. 73: 2013-2026

6. Kerr JFR and Harmon BV (1991) Definition and incidence of apoptosis: an historical perspective. In Apoptosis: the Molecular Basis of Cell Death, Tomei LD and Cope OF, eds. (New York: Cold Spring Harbor Laboratory Press) pp. 5-29

7. Darzynkiewicz Z, Juan G, Li X, Gorczyca W, Murakami T and Traganos F (1997) Cytometry in cell Necrobiology: analysis of apoptosis and accidental cell death (necrosis). Cytometry 27: 1-20

8. Arends MJ, Morris RG and Wyllie AH (1990) Apoptosis: the role of the endonuclease. Am. J. Pathol. 136: 593-608

9. Ishigami T, Kim KM, HoriguchiY, HigakiY, Hata D, Heike T, Katamura K, Mayumi M and Mikawa H (1992) Anti-IgM antibody-induced cell death in a human B lymphoma cell line, B104, represents a novel programmed cell death. J. Immunol. 148: 360-368

10. Matsuoka S, Asano Y, Sano K, Kishimoto I, Yorifuji H, Utsuyama M, Hirokawa K and Tada T (1995) A novel type of cell-death of lymphocytes induced by a monoclonal antibody without participation of complement. J. Exp. Med. 181: 2007-2015

11. Bhat NM, Bieber MM, Stevenson FK and Teng NNH (1996) Rapid cytotoxicity of human B lymphocytes induced by VH4-34 (VH4.21) gene-encoded monoclonal antibodies. Clin. Exp. Immunol. 105: 1-8

12. Hagar H, Ueda N and Shah SV (1997) Tyrosine phosphorylation in DNA damage and cell death in hypoxic injury to LLC-PK1 cells. Kidney Intl. 51: 1747-1753 
13. Papadimitriou JC, Drachenberg CB, Shin ML and Trump BF (1994) Ultrastructural studies of complement mediated cell death: a biological reaction model to plasma membrane injury. Virch. Arch. 424: 677-685

14. Kim SH, Carney DF, Papadimitriou JC and Shin ML (1989) Effect of osmotic protection on nucleated cell killing by C5b-9: Cell death is not affected by the prevention of cell swelling. Mol. Immunol. 26: 323-331

15. Green HR, Barrow P and Goldberg B (1959) Effect of antibody and complement on permeability control in ascites tumour cells and erythrocytes. J. Ex. Med. 110: $699-713$

16. Shipley WU, Baker AR and Colten HR (1971) DNA degradation in mammalian cells following complement-mediated cytolysis. J. Immunol. 106: 576-579

17. Nicoletti I, Migliorati G, Pagliacci MC, Grignani F and Riccardi C (1991) A rapid and simple method for measuring thymocyte apoptosis by propidium iodide staining and flow cytometry. J. Immunol. Meths. 139: 271-279

18. Gold R, Schmied M, Giegerich G, Breitschopf H, Hartung HP, Toyka KV and Lassman H(1994) Differentiation between cellular apoptosis and necrosis by the combined use of in-situ tailing and nick translation techniques. Lab. Invest. 71 : 219-225

19. Campbell AK, Daw RA and Luzio JP (1979) Rapid increases in intracellular free $\mathrm{Ca}^{2+}$ induced by antibody plus complement. FEBS. Lett. 107: 55-60

20. Campbell AK, Daw RA, Hallett MB and Luzio JP (1981) Direct measurement of the increase in intracellular free calcium ion concentration in response to the action of complement. Biochem. J. 194: 551-560

21. Kim S, Carney DF and Shin ML (1987) Nucleated cell killing by complement: Effects of C5b-9 channel size and extracellular $\mathrm{Ca}^{2+}$ on the lytic process. J. Immunol. 138: 1530-1536

22. Gaido ML and Cidlowski JA (1991) Identification, purification and characterisation of a calcium-dependent endonuclease (NUC18) from apoptotic rat thymocytes. J. Biol. Chem. 266: 18580-18585

23. Peitsch MC, Hesterkamp T, Polzar B, Mannherz HG and Tschopp J (1992) Functional characterisation of serum DNase I in MRL-Ipr/lpr mice. Biochem. Biophys. Res. Commun. 186: 739-745

24. Wyllie AH (1980) Glucocorticoid-induced thymocyte apoptosis is associated with endogenous endonuclease activation. Nature 284: 555-556

25. Wyngaarden JB and Smith LH (1988) Cecil Textbook of Medicine (Philadelphia W.B. Saunders Company) pp. 2395

26. Peitsch MC, Mannherz HG and TschoppJ (1994) The apoptosis endonucleases: cleaning up after cell death? Trends Cell Biol. 4: 37-41

27. Kishi K, Yasuda T, Ikehara Y, Sawazaki K, Sato W and lida R (1990) Human serum deoxyribonuclease I (DNase I) polymorphism: Pattern similarities among isozymes from serum, urine, kidney, liver and pancreas. Am. J. Hum. Genet. 47 $121-126$

28. Love JD and Hewitt RR (1979) The relationship between human serum and human pancreatic DNase I. J. Biol. Chem. 254: 12588-12594

29. Paddenberg R, Wulf S, Weber A, Heimann P, Beck L and Mannherz HG (1996) Internucleosomal DNA fragmentation in cultured cells under conditions reported to induce apoptosis may be caused by mycoplasma endonucleases. Eur. J. Cel Biol. 71: $105-119$

30. Lacks SA (1981) Deoxyribonuclease I in mammalian tissues - specificity of inhibition by actin. J. Biol. Chem. 256: $2644-2648$
31. ShackJ (1957) Deoxyribonucleases of mouse tissues. J. Biol. Chem. 226:573581

32. HerriotRM, Connolly JH and Gupta S (1961)Blood nucleases and infectious viral nucleic acids. Nature 189: $817-820$

33. Polzar B and Mannherz HG (1990) Nucleotide sequence of a full length cDNA clone encoding the deoxyribonuclease I from the rat parotid gland. Nuc. Acids Res. 18: 7151

34. Sakahira H, Enari M and Nagata S (1998) Cleavage of CAD inhibitor in CAD activation and DNA degradation during apoptosis. Nature 391: $96-99$

35. Booth C and Koch GL (1989) Perturbation of cellular calcium induces secretion of luminal ER proteins. Cell 59: 729 -737

36. Henkart PA (1985) Mechanism of lymphocyte-mediated cytotoxicity. Ann. Rev. Immunol. 3: 31-58

37. Lowrey DM, Aebischer T, Olsen KJ, Lichtenhelf M, Rupp F, Hentgartner $\mathrm{H}$ and PodackER (1989) Cloning, analysis and expression of murine perforin 1 cDNA, a component of cytotoxic T-cell granules with homology to complement component C9. Proc. Natl. Acad. Sci. U.S.A. 86: 247-251

38. Selsted ME and Oullette AJ (1995) Defensins in granules of phagocytic and nonphagocytic cells. Trends Cell Biol. 5: 114-119

39. Collins RJ, Harmon BV, Gobe GC and Kerr JFR (1992) Internucleosomal DNA cleavage should not be the sole criterion for identifying apoptosis. Intl. J. Radiat. Biol. 61: 451-453

40. Peitsch MC, Muller C and TschoppJ (1993) DNA fragmentation during apoptosis is caused by frequent single-strand cuts. Nucl. Acids Res. 18: 4206-4209

41. Chitrabamrung S, Rubin RL and Tan EM (1981) Serum deoxyribonuclease-I and clinical activity in systemic lupus erythematosus. Rheumatol. Int. 1:55-60

42. Matsui H, Tsuji S, Nishimura H and Nagasawa S (1994) Activation of the alternative pathway of complement by apoptotic Jurkat cells. FEBS Lett. 351: 419-422

43. Tsuji S, Kaji K and Nagasawa S (1994) Activation of the alternative pathway of human complement by apoptotic human umbilical vein endothelial cells. J. Biochem. 116: 794-800

44. Botto M, DellAgnola C, Bygrave AE, Thompson EM, Cook HT, Petry F, Loos M, Pandolfi PP and Walport MJ (1998) Homozygous C1q deficiency causes glomerulonephritis associated with multiple apoptotic bodies. Nature Genet. 19: $56-59$

45. Abraha A, Morgan BP and Luzio JP (1988) The preparation and characterisation of monoclonal antibodies to human complement component $\mathrm{C} 8$ and their use in purification of C8 and C8 subunits. Biochem. J. 251: 285-292

46. Clark EA, Shu G and Ledbetter JA (1985) Role of the Bp35 cell surface polypeptide in human B-cell activation. Proc. Natl. Acad. Sci. U.S.A. 82: $1766-$ 1770

47. Glennie MJ, Tutt AL and Greenman J (1993) Preparation of multispecific $F\left(a b^{\prime}\right)_{2}$ and $\mathrm{F}\left(\mathrm{ab} \mathrm{b}_{3}\right)_{3}$ antibody derivatives. In Tumour Immunobiology, a Practical Approach, Rees RC, Reynolds CW, eds. (Oxford: Oxford University Press) pp. $225-244$

48. Nieto MA and Lopez-Rivas A (1989) IL-2 protects T lymphocytes from glucocorticoid-induced DNA fragmentation and cell death. J. Immunol. 143: $4166-4170$ 